\title{
Analysis of the workload of bank tellers of a Brazilian public institution
}

\author{
Simoni S. Serikawa ${ }^{\mathrm{a}^{*}}$, Ana Carolina S. Albieri ${ }^{\mathrm{a}}$, Gustavo P. Bonugli ${ }^{\mathrm{a}}$, Marina F. Greghi ${ }^{\mathrm{a}}$ \\ a. CENTRO UNIVERSITÁRIO SENAC, Avenida Capitão Salomão, 2133, Ribeirão Preto, SP, Brazil, 14085430.
}

\begin{abstract}
During the last decades there have been many changes in the banking sector organization. It has been also observed the mutual growing of musculoskeletal and mental disorders. This study investigated the workload of bank tellers at a Brazilian public institution. It was performed the Ergonomic Work Analysis (EWA). Three employees participated in this study. During the analysis process, three research instruments were applied: Inventory of Work and Risk of Illness, Yoshitake Fatigue Questionnaire and Nordic Musculoskeletal Questionnaire, beyond the realization of footage recordings and the self-confrontation. The results indicated the existence of an excess of workload on the evaluated workstations, mainly in relation to mental order constraints, that overlaps the physical aspects. Thereby it was found that the employees tend to adopt strategies trying to reduce the impacts of the excess of workload, in order to regulate it.
\end{abstract}

Keywords: Bank teller, workload, Ergonomic Work Analysis.

\section{Introduction}

The banking sector has undergone major changes in recent decades due to technological and market changes. Programs to mass dismissals, automation and outsourcing were implemented [2]. Within these changes it was observed among the employees a growing of musculoskeletal disorders related to work [3] but the literature shows that psychological factors also affect the employees' health that are often not identified [5].

The bank tellers have a stressful job, which may be the source of psychic disorders [5]. They report fatigue complaints and dissatisfaction. They also have complaints about the environment, pressure of superiors and the furniture [7].

Beyond the monotonous and repetitive work, they need to handle with public service. This is complex and involves the attendant's, the institution's and the customers' logic. These logics need a balance, so there are not critic indicators, such as the waiting time of the customer, rework, mistakes, etc. [4].

Facing this scenario, the Ergonomic Work Analysis (EWA), according to Salerno (2000), has as basic characteristic the systematic observation of the real work, beginning through the prescribed analysis [6].

The present study intends to analyze the work of bank tellers of a Brazilian public institution, in order to identify the physical, cognitive and psychic workload present on these situations.

\section{Methodological Formulation}

It was performed the Ergonomic Work Analysis (EWA) in three workstations. The EWA involves the phases: demand analysis, task analysis, activity analysis and diagnose.

\subsection{Procedures}

The main complaints and causes of absenteeism of tellers were investigated. Then the data was collected through the instruments: Inventory of Work and Risk of Illness, Yoshitake Fatigue Questionnaire and Nordic Musculoskeletal Questionnaire.

Images of the workstation were taken and footage recording of the activities. The information was ana-

\footnotetext{
Corresponding author. E-mail: fisio.simoni@gmail.com. Alameda das Hortências, 271, São Carlos, SP, Brazil, 13566533.
} 
lyzed and devolved to the participants through the self-confrontation., to deepen the questions that the researchers had investigated. By means of the process of validation and devolution with the employees, it was done a diagnostic about the workload.

\subsection{Sample Characterization}

Two bank tellers and a head teller were part of the study. All of them women between ages of 31 to 42 . Two have an Undergraduate degree and one, only high school. The work experience varies from 2 to 9 years.

\section{Results}

\subsection{Demand analysis}

The bank agency has a moderated flow of about 200 people per day. There are days with larger demands for services, as payment day, and those with less demand, as half of the month until the end.

\subsection{Task analysis}

The recruitment process and the selection of employees are through civil service admission exam. There are career plan, internal concourses, scores for courses, opportunity for commissioned positions, and rise on merit. The head teller is considered a position of trust, after working as bank teller.

The bank tellers work 6 hours per day, with lunch pauses of 15 minutes and 10 minutes each hour during the work time. They work overtime only in busy days. The mean value of hours of service of the interviewed was 32.5 hours per week.

\subsubsection{Tasks descriptions}

According to the manager, the main tasks of a head teller are: close the cashier, open the bank pouches and envelopes, payment and prepare bank pouches, distribute and separate the change, record the transactions, handle and count money (in cash), and make the bank secrecy. The bank teller should give a nice treatment to the customer, make a good image of the bank; open cashier; receive several receipts; provide various information, checkbooks, bank balances, cards, etc.; make conference signatures; end the tape box, and make the bank secrecy.

\subsection{Activities analysis}

It was observed that even with the pressure and task control, the tellers can adapt and modify their services, adopting strategies to minimize the excess of workload imposed (Table 1).

Table 1

Strategies and Workload

\section{Physical workload}

A 1. Does regular exercises to minimize the discomfort;

2. Blocks the air passage, because this is right in the

direction of the employee;

3. Avoids the contact with the money counting machine to avoid contamination.

B 1. Tries to keep the best posture to avoid pain;

2. Uses a cream to pain

C 1. Uses a ruler to cut papers;

2. Sits on the edge of the chair due the displacement caused by the constant opening of the drawer;

3. Takes pain killers.

Cognitive Workload

A 1. Creates a routine and organization to not forget steps.

B 1. Keeps the bills in a drawer to facilitate the closing of the cashier in the end of the day.

C 1. First receives the money then after does the payment; 2. Organizes the position of the objects to not lose bills. Psychic Workload

A 1. Keeps attention to avoid mistakes.

B 1. Creates a sequence to not forget steps;

2. Adds and counts twice the bills to avoid mistakes;

3. Necessary, in some cases, to elevate the voice tune to handle with the customer;

4. Keeps attention to avoid mistakes.

C 1. Creates a sequence to not forget steps;

2. Adds and counts twice the bills to avoid mistakes;

3. Tries not to get distract with customers;

4. Necessary, in some cases, to elevate the voice tune to

handle with the customer;

5. Keeps attention to avoid mistakes.

$\mathrm{A}=$ Head teller, $\mathrm{B}=$ Bank teller $1 \mathrm{C}=$ Bank teller 2

It was observed lack of space between the desks and difficulties to movement in the office of the head teller. It is also needed a support desk to use the money counting machine. About the cognitive workload, he told about the fear of mistakes and the eventual financial loss. When asked about his activity and workload, he made an analogy related to the exposition time in the sun and how this can be harmful.

(...) Like if you walk on the beach I think, on a haze day. You think you are not getting a tan, but in the end of the day you are all reddish, right? I don't notice in the day by day that it's harming me, but I guess, in a long time ahead, it may harm some way. 
As a bank teller, the dissatisfaction is the disposition of the balcony that permits the access of the customer, making vulnerable to robbery. Considering the furniture, the disposition of the cash drawer under the desk is not adequate. There is a need to move the chair, making the employees sit only in the anterior seat to move easily. About their activities and physical workload present, an employee said:

(...) Truly they are fully repetitive movements, you get the money, count, put on the machine, open the drawer, close the drawer $(. .$.$) every time is the same sequence.$

\subsection{Employees' perception related to activity}

\subsubsection{Inventory of Work and Risk of Illness}

The major constraints scored by the employees are about the organizational, the physical and the mental workload. To these variables, all the participants had alert or critical classification.

\subsubsection{Yoshitake Fatigue Questionnaire}

The score of fatigue vary from 30 to 150 points, which indicates the lowest to the largest fatigue. The scores found are satisfactory. The score of the head teller was 80, the bank teller 1, 53 and teller 2, 36 .

\subsubsection{Nordic Musculoskeletal Questionnaire}

The figure 1 illustrates the places of physical disorders. It was observed that the head teller has larger nuisance than other bank tellers.

Figure 1. Places with pain, discomfort or numbness: a. Last 12 months; b. Last 7 days; c. Avoided from activities on the last 12 months

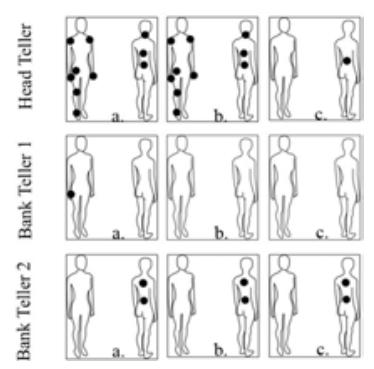

\subsection{Diagnose}

The institution imposes goals to the employees takes into a repetitive, monotonous and under pressure job. The repetitiveness and monotony leads to constraints of mental nature. There is the need to move away from the thought in order to reach good production performances. A way of not thinking is to accelerate the activity, decreasing the cycle length [1]. This can be observed in the fact of employees keep the rhythm even in days with less demand.

The employees also should represent the institution working under its rules, even if the teller shows a depersonalization figuring the institution [4].

Overall, there were larger constrained related to aspects of organizational and mental workload. The employees have strategies for reducing this load. According to Dejours (2000), "individual strategies and collective strategies in many cases, allow you to control the deleterious effects of stress on mental health" [1].

\section{Discussion and Conclusion}

It can be concluded that on tellers' activities studied, there is an overload mainly related to the mental workload aspects that overlaps the physical ones. Thus, it was found that the strategies adopted by employees tend to reduce the impact of this overload.

Through the self-confrontation, there were antagonistic statements front the same situation. Employees under the same constraints showing that individuality should be respected while proposing solutions.

\section{References}

[1] C. Dejours, Novas Formas de Organização do Trabalho e lesões por esforços repetitivos (LER): Abordagem da psicodinâmica do Trabalho. In Trabalho Humano com sistemas informatizados no setor de serviços, São Paulo: Editora Plêiade, 2000, 465 p.

[2] C.L.R. Cruz and M.L.B. Gomes, Automação competitividade no setor bancário: o caso dos bancos públicos, In: ENEGEP, Niterói - Rio de Janeiro: Abepro (1998), pp.1-8

[3] J. T. Dennerlein and P.W. Johnson, Different computer tasks affect the exposure of the upper extremity to biomechanical risk factors, Ergonomics, 2006, pp. 45-61.

[4] M. Ferreira, Serviço de Atendimento ao Público: O que é? Como analisá-lo? Esboço de uma Abordagem TeóricoMetodológica em Ergonomia, Revista Multitemas, 1, 2000, pp.128-144.

[5] M. Palácios et al., Trabalho e sofrimento psíquico de caixas e agências bancárias na cidade do Rio de Janeiro, Cad Saúde Pública, 18, 2002, pp. 637-646.

[6] M.S. Salerno, Análise Ergonômica do Trabalho e Projeto Organizacional: uma Discussão Comparada. ABEPRO, número especial, 200, pp.45-60.

[7] S. M. Rosso, A favor do trabalho, flexibilidade de uso, conforto ambiental e ergonomia são alguns dos fatores decisivos que geram espaços corporativos agradáveis e estimulantes, Revista AU, 156, 2006. 